Portland State University

PDXScholar

\title{
8-2013
}

\section{Contesting Sustainability: Bikes, Race, and Politics in Portlandia}

\author{
Amy Lubitow \\ Portland State University, alubitow@pdx.edu \\ Thaddeus R. Miller \\ Portland State University, trm2@pdx.edu
}

Follow this and additional works at: https://pdxscholar.library.pdx.edu/usp_fac

Part of the Sustainability Commons, Urban Studies Commons, and the Urban Studies and Planning Commons

\section{Let us know how access to this document benefits you.}

\section{Citation Details}

Lubitow, A., \& Miller, T. R. (2013). Contesting Sustainability: Bikes, Race, and Politics in Portlandia. Environmental Justice (19394071), 6(4), 121-126.

This Article is brought to you for free and open access. It has been accepted for inclusion in Urban Studies and Planning Faculty Publications and Presentations by an authorized administrator of PDXScholar. Please contact us if we can make this document more accessible: pdxscholar@pdx.edu. 


\title{
Contesting Sustainability: Bikes, Race, and Politics in Portlandia
}

\author{
Amy Lubitow and Thaddeus R. Miller
}

\begin{abstract}
Despite decade old calls for a "just sustainability," urban sustainability policy and practice remains oriented toward environmental outcomes and eco-lifestyle projects. Notions of equity, justice, and inclusion continue to be marginalized in favor of technological solutions, such as green buildings, that are visible, easy to implement, and help to promote economic development. By examining a controversy over a bikeway development project in a rapidly gentrifying neighborhood in Northeast Portland, Oregon, this article explores how despite apolitical appeals to broadly shared values or visions of what a sustainable city ought to look like, sustainability projects can be-and perhaps should be-hotly contested. This article illustrates how sustainable development projects become sites of political debate, and provide space for environmental and social justice concerns to enter into the broader discourse on sustainability. Following the work of environmental justice advocates and scholars critiquing urban sustainability, this article contributes to the analysis and practice of efforts to advance a more socially robust, equitable, and political notion of sustainability.
\end{abstract}

\section{INTRODUCTION}

A decade ago Agyeman, Bullard, And Evans issued a call for a "just sustainability" that integrates social equity and justice into efforts to enhance the built environment. ${ }^{1}$ Yet, the dominant narrative of sustainability remains stubbornly oriented toward infrastructural interventions aimed at enhancing environmental outcomes. While these efforts provide quality of life benefits related to, for instance, public health or even sense of place, notions of equity, justice, or inclusion remain marginalized in discussions about how to construct sustainable infrastructure. $^{2,3}$ Sustainability practices, projects, and tech-

Dr. Lubitow is an assistant professor in the Department of Sociology at Portland State University in Portland, OR. Dr. Miller is an assistant professor at the Nohad A. Toulan School of Urban Studies and Planning, College of Urban and Public Affairs, at Portland State University.

${ }^{1}$ Agyeman, Julian, Robert D. Bullard, and Bob Evans (eds.). Just Sustainabilities: Development in an Unequal World. Cambridge: MIT Press, 2002.

${ }^{2}$ Moore, Steven. Alternative Routes to the Sustainable City: Austin, Curitiba, and Frankfurt. Lexington, KY: Lexington Books, 2007.

${ }^{3}$ Bryson, Jerome. "Brownfields Gentrification: Redevelopment Planning and Environmental Justice in Spokane, Washington. Environmental Justice 5(1) (2012): 26-31. nologies, particularly in urban settings, have largely focused on green space, green and/or living, buildings, or a variety of energy saving technologies. Such efforts, perhaps somewhat predictably, privilege sustainability projects that are highly visible (e.g., LEED- certified buildings), relatively quick to implement, have immediately visible and quantifiable results (e.g., reduction in electricity usage), and promote economic development.

This predisposition is problematic from an environmental justice standpoint. Scholars have routinely found that failure to include social and environmental justice issues in sustainability initiatives results in the inequitable distribution of the benefits of sustainable development and generates unintended consequences. ${ }^{4,5}$ Although scholarship on sustainability has recognized the need to incorporate social issues into discussions on sustainable

${ }^{4}$ Flocks, Joan, Francisco Escobedo, Jeff Wade, Sebastian Varela, and Claudia Wald. "Environmental Justice Implications of Urban Tree Cover in Miami-Dade County, Florida," Environmental Justice 4(2) (2011): 125-134.

${ }^{5}$ García, Robert and Erica Flores. "Anatomy of the Urban Parks Movement: Equal Justice, Democracy and Livability in Los Angeles," in The Quest for Environmental Justice: Human Rights and the Politics of Pollution, ed. Robert Bullard, 145-67, San Francisco: Sierra Club, 2005. 
futures, the distinct challenges facing environmental justice communities have been difficult to integrate into the broader practice of sustainability. ${ }^{6,7,8,9,10}$

We contend that the inability of environmental justice concerns to gain traction in discussions about the design of sustainable infrastructure is due in part to the depoliticization of sustainability projects. On issues from climate change to sustainable transportation, sustainability advocacy groups often treat such issues as apolitical, or, as some scholars have noted, post-political; ${ }^{11,12}$ that is, a given problem, project, practice, or policy is framed as urgent and necessary by appealing to universal values or scientific knowledge claims related to ecological health or public health and safety. ${ }^{13}$ Sustainability, in other words, rises above what are perceived as parochial concerns and is too important to be dragged through the political mud. As Žižek notes, the "universalization of particular demands" is used "to reduce the overall demand (complaint) of a particular group to justify this demand with its particular content." 14 The result is that issues amenable to technological solutions, such as energy efficiency upgrades or even transportation infrastructure, are able to move forward while thorny political issues regarding race and inequality are sidestepped. On the other hand, this also serves as a challenge to the environmental justice community. The ability of sustainability advocates to integrate diverse values and politics behind certain technological solutions should spur scholarship and action on environmental justice that explores the possibility of designing more just and equitable technologies and infrastructures.

This article utilizes a case study from Portland, OR involving a conflict over bikeway development in a rapidly gentrifying neighborhood to explore how pervasive notions of sustainability that dominate urban development practices tend to emerge as apolitical discussions that appear settled or as broadly appealing. We clarify how what initially appeared to many to be a universal public good (at least in Portland)-bikeway develop-

${ }^{6}$ Portney, Kent E. and Jeffrey M. Berry. "Participation and the Pursuit of Sustainability in U.S. Cities," Urban Affairs Review 46(1) (2010): 119-139.

${ }^{7}$ Agyeman, Julian, Robert D. Bullard, and Bob Evans. "Exploring the Nexus: Bringing Together Sustainability, Environmental Justice and Equity," Space \& Polity 6 (2002):77-90.

${ }^{8}$ Warner, Kee. "Linking Local Sustainability Initiatives with Environmental Justice," Local Environment 7 (2002): 35-47.

${ }^{9}$ Brugmann, Jeb. "Is there a Method in Our Measurement? The use of Indicators in Local Sustainable Development Planning," Local Environment 2 (1997): 59-72.

${ }^{10}$ Yanarella, Earnest. "Local Sustainability Programmes in Comparative Perspective: Canada and the USA," Local Environment 4 (1999): 209-24.

${ }^{11}$ Žižek, S. The Ticklish Subject: The Absent Centre of Political Ontology. London: Verso, 1999.

${ }^{12}$ Swyngedouw, Eric. "The Antinomies of the Postpolitical City: In Search of a Democratic Politics of Environmental Production." International Journal of Urban and Regional Research 33(3) (2009):601-620.

${ }^{13}$ Miller, Thaddeus R. "Constructing Sustainability Science: Emerging Perspectives and Research Trajectories." Sustainability Science 8(2) (2013): 279-293.

${ }^{14}$ Žižek 1999:204. ment-opened up a highly contested terrain, forcing planning efforts to confront issues of gentrification and a history of exclusionary planning policies and practices. This article illustrates how sustainable development projects in urban areas can become sites of intense political discussion and contestation, opening up opportunities for environmental and social justice concerns to become part of the broader discourse on sustainability as well as specific conversations about the design of technologies and infrastructures meant to meet sustainability goals.

In what follows we focus our analysis on a bikeway development project in Portland, the North Williams Traffic Safety Operations Project. We build our discussion from reviews of relevant public documents, observation at public meetings from August 2011 through June 2012, and interviews with 19 individuals, including citizens and governmental employees, involved in the decision-making process. We begin by describing Portland's particular commitment to sustainability, move on to provide the context of this case study and the social history of the surrounding neighborhood, and make specific arguments about how bikeway development came to be an unsettled aspect of urban development in Portland. We conclude in suggesting that sustainability is, and must be, a constantly negotiated, contested, and inherently political concept. ${ }^{15,16}$ By uncovering the politics of sustainability in Portland and critiquing the conventional vision of urban sustainability, we intend to build upon the work of environmental justice advocates and scholars in hopes of advancing a more socially robust, equitable, and political notion of sustainability.

\section{SUSTAINABILITY IN PORTLAND, OREGON}

Portland, OR, a city of nearly two million people, has been lauded as one of the most sustainable cities in America. With a long and well-documented history of progressive urban and regional planning, Portland has come to serve as a beacon of sustainable urban development and sustainable lifestyles. ${ }^{17,18,19}$ Portland is home to the nation's only elected regional governing body, Metro, and the nation's first city agency dedicated to sustainability, the Bureau of Planning and Sustainability (BPS). Over the last two decades, Metro, BPS, and other city agencies (including the Bureau of Transportation and the Bureau of Environmental Services), spurred on by strong community engagement efforts, have been aggressive in

\footnotetext{
${ }^{15}$ Krueger, Rob and David Gibbs. Urban Political Economy in the United States and Europe. New York: Guilford Press, 2007.

${ }^{16}$ Norton, Bryan. Sustainability: A Philosophy of Adaptive Ecosystem Management. Chicago, IL: Chicago University Press, 2005.

${ }^{17}$ Adler, Sy. Oregon Plans: The Making of an Unquiet Land Use Revolution. Corvallis, OR: Oregon State University Press, 2012.

${ }^{18}$ Seltzer, Ethan. "Regional Planning and Local Governance: The Portland Story," in Sustainable City Regions 7 (2008): 277-98.

${ }^{19}$ Portney, Ken. "Sustainability in American Cities: A Comprehensive Look at What Cities Are Doing and Why," in Toward Sustainable Communities: Transition and Transformations in Environmental Policy, edited by Daniel A. Mazmanian and Michael E. Kraft, 227-54, Cambridge: MIT Press, 2009.
} 
advancing city-wide initiatives to support green building, recycling and composting, public transit, and bicycling infrastructure. These efforts have not gone unnoticed in the city ranking industry. The SustainLane ranking system, for instance, has routinely named Portland the "greenest city" in the U.S. ${ }^{20}$ Despite dim employment prospects, the pull of "Portlandia" has resulted in substantial migration to the metropolitan area driven in part by its image as a green or sustainable city-not to mention its reputation as a hipster haven. ${ }^{21}$

A significant aspect of the vision for a sustainable Portland lies in its embrace of bicycling infrastructure as a mechanism to meet environmental goals (via reducing greenhouse gas emissions and local air pollution) and expand economic opportunities (via increased traffic to local businesses) while enhancing Portland's image as a cool, hip, walkable, and bikeable eco-friendly metropolis. In 2010, for example, the Portland City Council adopted the Portland Bicycle Plan for 2030, which not only commits the city to expanding planned bikeways from 630 to 962 miles, but also includes plans to increase the number of regular cyclists and promotes the ultimate goal of mixed-use neighborhoods in which basic services are a bike ride away.

The commitment to this vision is widely supported by the thousands of regular cyclists who advocate for the continued expansion of cycling infrastructure and amenities and has earned Portland the accolades as a bikeable city. In 2012, Portland received the highest ranking of Platinum as a "bike friendly city" from the League of American Cyclists, while Bloomberg ranked Portland as the "best bike-to-work city" in the U.S. ${ }^{22}$ Cycling infrastructure in Portland has emerged as a seemingly uncontestable public good that advances multiple city-wide assumptions about the type of place Portland is and should be. Bicycles and the infrastructure that supports them have become a central technology and cultural symbol of sustainability in Portland and also serve as an example of how sustainability, according to Davidson, has become a master-signifier in urban planning and policy. ${ }^{23,24}$

Despite the seemingly settled nature of cycling as a foundational element of Portland's vision for a sustainable future, efforts by the Portland Bureau of Transportation

\footnotetext{
${ }^{20}$ Sustainlane. How Green is Your City: Sustainlane US City Rankings. Gabriola Is, BC: New Society Publishers, 2008.

${ }^{21}$ Jurjevich, Jason and Greg Schrock. "Is Portland Really the Place Where Young People Go To Retire? Migration Patterns of Portland's Young and College Educated, 1980-2010." Report, Portland State University, accessed Mar. 25, 2013, < http://mkn .research.pdx.edu/wp-content/uploads/2012/09/JurjevichSchrock MigrationReport1.pdf $>$.

22 "League of American Bicyclists Bicycle Friendly Community Program," accessed Apr. 11, 2013, <http://www.bikeleague .org/programs/bicyclefriendlyamerica/communities/ >; "Portland is Top Bike To Work City as Lawyers Hit Street," accessed Apr. 11, 2013, <http://www.bloomberg.com/news/2012-05-22/ portland-is-top-bike-to-work-city-as-lawyers-hit-street.html $>$.

${ }^{23}$ Davidson, Mark. "Sustainability as Ideological Praxis: The Acting Out of Planning's Master-Signifier." City 14(4) (2010): 390405.

${ }^{24}$ Gunder, Michael and Jean Hillier. Planning in Ten Words or Less. Burlington, VT: Ashgate Publishing Company, 2009.
}

(PBOT) in 2011 to enhance a 28-block long bikeway on the east side of the Willamette River in a Northeast Portland neighborhood was met with substantial community opposition. How did a seemingly innocuous bikeway development project become such a magnet for debate? What can this controversy (and its tentative resolution) tell scholars and practitioners concerned with just sustainability about the social and political dimensions of sustainability in Portland and beyond? We now turn to a discussion of the emergence of the controversy over the planned bikeway development project.

\section{THE NORTH WILLIAMS TRAFFIC SAFETY OPERATIONS PROJECT}

The North Williams Avenue corridor, located on the northeastern side of the Willamette River, was identified in 2010 by PBOT as a site for bikeway development due to ongoing conflicts between different transit modes. PBOT targeted this street due to the co-occurrence of heavy traffic from motor vehicles, bicycles, and buses (with an estimated 700 to 1,000 cars per hour throughout the corridor and certain segments of the street experiencing 3,000 bicycle trips each day). ${ }^{25}$ The North Williams Traffic Safety Operations Project, as part of PBOT efforts to improve cycling infrastructure, set aside $\$ 370,000$ for minor infrastructure improvements to reduce traffic conflicts on the street.

The previously noted Portland Bicycle Plan for 2030, whose goals promote using city policies to increase the density of the bikeway network as a primary means of advancing a "sustainable green economy," provided the impetus for PBOT's focus on North Williams Avenue. ${ }^{26}$ Given the breadth and depth of support for cycling in the city, transportation officials did not expect the relatively small North Williams project to draw much attention from residents or community members. However, the planning process became a contested venue in which larger concerns over racism, gentrification, and historical inequities took center stage.

North Williams Avenue is situated in a rapidly gentrifying part of the city that had once been home to the majority of Portland's African American population. ${ }^{27}$ Ongoing development and the influx of younger, white professionals into the neighborhood has rapidly transformed North Williams Avenue over the last fifteen years. As such, the nearly two mile long road that once housed black-owned businesses, restaurants, and homes, has come to be heavily populated with white-owned boutiques, restaurants, and bars.

Sensitive to these issues, PBOT sought to bring a diverse group of stakeholders together to help in this

\footnotetext{
${ }^{25}$ Bower, Dan et al. Portland's Platinum Bicycle Master PlanExisting Conditions Report. Retrieved Mar. 25, 2013, <http:// www.portlandoregon.gov/transportation/article/369982 > .

${ }^{26}$ Portland Bureau of Transportation. The Portland Bicycle Plan for 2030. 2011, xvi.

${ }^{27}$ Gibson, Karen. "Bleeding Albina: A History of Community Disinvestment," Transforming Anthropology 15 (2007): 3-25.
} 
decision-making process. As is common practice in Portland, PBOT organized a stakeholder advisory committee (SAC) of interested business owners, residents, and key stakeholders living or working along North Williams Avenue who would be tasked with advising the city on how to best alter the street. Typically SAC meetings are convened for four to six months and the committee concludes by presenting their recommendations for how the city should proceed. In soliciting participants for the North Williams SAC, city staff engaged a variety of outreach methods intended to target a diverse group of stakeholders. A consultant hired by the city to help with recruitment sought community participants by canvassing door-to-door, by sending postcards to all residents and businesses along the street, and by sending e-mails to local neighborhood associations and community organizations. Open meetings were also held to secure participation, while the African American churches on or adjacent to the street were contacted.

Despite this extensive outreach, when the initial SAC convened in early 2011, only four of the 22 members present were people of color. This lack of diverse representation, when coupled with historical legacies of racism and inequality that characterized the African American experience in the North Williams area, served as a catalyst for community grievances around this project to emerge. In the next two sections, we highlight the politics and processes surrounding the emergence of competing visions of community and sustainability that characterized this project. On the one hand, decision makers working for the city of Portland developed a narrative around bike lane expansion that highlighted the importance of improving safety on the street, reducing accidents and promoting ease of movement for cyclists and commuters. On the other, long-time African American residents responded to the city's framing of the project by articulating a competing narrative that acknowledged an extensive history of exclusionary development, displacement, and gentrification in the area.

\section{SUSTAINABILITY AS APOLITICAL: NARRATIVES OF SAFETY AND ACCESS}

The dominant vision of sustainability in Portland detailed above suggests that for many residents of Portland, as well as for a vocal and connected cycling advocacy community, cycling infrastructure is seen as a critical suite of technologies for long-term sustainability and a central symbol for what sustainability means in Portland. Cycling advocates, including the widely read blog, BikePortland.org, were quick to actively voice support the project, as North Williams Avenue had become notorious in the cycling community for having serious safety concerns related to conflicts between bicycles and other modes of transportation, including buses. Decisions related to how, where, and why to utilize city resources were perceived by many to be predetermined in favor of bike lane expansion given its prominence in city initiatives as well as the presence of a vocal and organized advocacy community. Initially, PBOT and cycling advo- cates framed the project as an apolitical issue dealing with bicycle safety and access-pushing aside, for the moment at least, deeper political issues related to the history of the area and the public participation process.

In interviews and during public meetings, the most outspoken cyclists routinely discussed the project solely in terms of safety, access, or a generalized sense of the environment. One prominent blogger covering the project characterizes the routine framing of the project as a safety issue, noting "If we delay this safety campaign and project for a year, and in that time another first grader is hit and killed, I'd feel that it was a huge failure on our part as a community." ${ }^{28}$ Another bike commuter noted his concern about pedestrian conflict with cyclists and reported that his primary interest in participating on the SAC was to promote greater ease of movement for pedestrians- ${ }^{\prime \prime} \mathrm{I}$ want people to walk across the street at any spot and not think twice about it." 29

The apolitical framing around safety and access led to a genuine sense of surprise at the emergence of the controversy over how to develop the street (detailed below): "We had an opportunity...in this city to be the undisputed leader in building a city where it's easy to bike, like getting something close to what you can do in Europe." ${ }^{\prime 30}$ These comments typified the responses of many avid cyclists who presumed cycling infrastructure development to be a universal public good supported by the city and its citizens. For adherents to this narrative, this was not a political issue about past injustices or current patterns of gentrification; it was a matter of safety and even an issue regarding the broader standing of Portland as a bike-friendly city.

\section{POLITICIZING SUSTAINABILITY: NARRATIVES OF INJUSTICE AND EXCLUSION}

As a distinct narrative about the project emerged from active cyclists, a different and distinct narrative emerged from within the African American community, merging historical injustices in the community with their concerns about ongoing changes to the street. Racist real-estate practices and inequitable development that had occurred in the North Portland area over the course of the previous 50 years were linked to present-day gentrification and marginalization in ways that politicized the discourse surrounding the North Williams project.

Portland, like many other American cities in the post-WWII era, was the site of both redlining and discriminatory lending practices that targeted minority community members. The outcome of such practices in the 1950s was the de facto segregation of black residents within the North Portland neighborhood and the devaluation of property to values well below the median for

\footnotetext{
${ }^{28}$ Bike Portland, Blog. "Meeting on Williams Project Turns into Discussion of Race, Gentrification." Retrieved Mar. 25, 2013, $<$ http://bikeportland.org/2011/07/21/racism-rears-its-head-onwilliams-project-56633>.

${ }^{29}$ Personal Interview, March 2012.

${ }^{30}$ Personal Interview, April 2012.
} 
the rest of the city. ${ }^{31}$ Subsequent development and urban renewal projects in the 1960s and early 1970s that targeted North Portland were devastating to the black community. These projects included the construction of two freeways, the Veteran's Memorial Coliseum, the Lloyd Shopping Center, and Legacy Emanuel Hospital. Each new development displaced hundreds of black-owned businesses and homes and appropriated residential areas for city development.

Public and private sector disinvestment in the North Portland neighborhood, coupled with the profound community dislocations that occurred in the 1960s and 1970s paved the way for the gentrification occurring in the neighborhood today. In the 1980s and early 1990s, the huge infrastructure projects that had bisected the North Portland area became even more problematic as declining private investments and lending opportunities further depressed property values in the neighborhood. This opened opportunities for developers to buy up vacant or inexpensive property in the neighborhood and, by 1999, blacks owned 53 percent fewer homes and whites owned 43 percent more than just a decade earlier. ${ }^{32}$

This history of exploitation and marginalization became a live political issue as black residents highlighted how the current attempt to recreate the street echoed earlier city dynamics that excluded African Americans from decision-making processes and sacrificed community interests for the sake of the city's vision. In media coverage of the North Williams project, in dialogue at public meetings, and in interviews with residents and SAC members, neighborhood history and context consistently emerged as a counter-narrative that challenged the notion of safety or development as usual. Two African American residents illustrate how past and present issues were merged into a more complex story about race and the history of the neighborhood:

It goes back to where freeways were built. There are only two houses left on the street...where my family grew up because they built the high school, the freeway, and the coliseum. The homes were just wiped out, and nobody had a say. The same thing has happened with Emanuel [Hospital] where it's just taken over an entire community of wiping out houses, but it's all for the good of the community...So it doesn't surprise me, but it's still very disturbing and angering to see that happen in 2013.

How can you draw conclusions and make decisions when it is pretty clear we [the African American community] have not been involved? We, the community, have not been involved, and this feels like another city grab like what has been done in the past. $^{33}$

Many residents noted that the influx of resources into the community coincided with gentrification and that

\footnotetext{
${ }^{31}$ Gibson, Bleeding Albina ...

${ }^{32}$ Gibson, Bleeding Albina ...

${ }^{33}$ Personal Interviews, March and April 2012.
}

the city did not wish to invest in black residents. The apolitical narrative of safety was challenged as an explicitly political issue: "You say you want it 'safe' for everybody, how come it wasn't safe 10 years ago? That's part of the whole racism thing...we wanted safe streets back then; but now that the bicyclists want to have safe streets then it's all about the bicyclists getting safe streets." 34

The salience of racism, gentrification, and historical exclusion in a relatively mundane traffic operations project illustrates how issues of sustainability are unsettled. The two contrasting visions of bikeway development in Portland reveal that visions of sustainability may vary greatly. Historical and ongoing injustices within a community can significantly impact the traction that sustainable initiatives might have, suggesting that a more just sustainability must encourage the politicization of the concept and the integration of numerous voices into a community's vision for the future.

The politicization of the North Williams project ultimately served to alter the city's approach to planning the street. Demands for a more inclusive planning process with a more diverse stakeholder committee were met and a series of community dialogue sessions around gentrification and racial discrimination emerged to aid in acknowledging past grievances within the African American community in Portland. The SAC, with more minority members participating, redrafted plans for the street in a unique fashion that attempted to balance the needs of all stakeholders and modes of transportation, while the contestation of the process itself served to generate broader discussions of the social aspects of sustainability (e.g. access to jobs, affordable housing, business loans for minorities). What began as a quick and "easy" transportation project blossomed into a much larger conversation about the social sustainability of neighborhoods and ultimately lead to an alternative design for the project-one that included values and concerns related to equality and justice.

\section{CONCLUSION: TOWARDS A MORE JUST URBAN SUSTAINABILITY}

The case of North Williams Avenue demonstrates that as cities gravitate toward narrow apolitical notions of sustainability, more nuanced considerations of environmental justice, race, and health become marginalized. The depoliticization and routine "tunnel vision" that dominates sustainable urban planning obscures the myriad social concerns that are just as critical to community vitality and longevity. Over time, the entrenchment of apolitical sustainable development into city imperatives and priorities means that environmental justice communities are less and less likely to see themselves in such visions of sustainability and opportunities for re -envisioning community futures are reduced. By avoiding

\footnotetext{
${ }^{34}$ Public meeting, July 20, 2011.
} 
the political, issues of race, justice, and equity are often excluded and it can be difficult for groups whose perspectives are being marginalized to open or politicize sustainability problems and projects.

However, as this case study has demonstrated, there are critical moments in which the notion of sustainabilityand the boundaries that maintain it-can be challenged, critiqued, and potentially altered in pursuit of a more inclusive vision. The counter-narrative of race and justice politicized the project, opening it to discussions about justice and historical legacies of racism. We suggest that the environmental justice movement can, and should, seek to politicize sustainability in ways that will open up the concept of sustainability to the range of social and economic priorities that continue to impair the health and well-being of low-income and minority communities. Cities interested in embracing the idea of sustainability should not assume that the broader popularity of "green" infrastructural changes will meet community demands for greater efficiency, security, or safety; rather, planners and decision makers should assume that all community members have a unique vision for their local environment and that their input is a critical mechanism for truly sustainable outcomes - and for formulating a vision of sustainability that resonates with a broader set of constituents. An important implication is that sustainability advocates must sometimes let go of a privileged vision of sustainability that might include a eco-friendly lifestyle, bicycling, and green buildings. This case illustrates that what is sustainable will be contextual and contested. Community members can, and should, demand a seat at the table when decisions regarding sustainability are being made. Sustainable urban planning remains in its infancy in the U.S. and this moment is therefore a critical time for community members to engage with decision makers to ensure that sustainability comes to be defined in as broad and socially just means as possible-and, as the North Williams project also demonstrates, find ways to engage so as to alter the actual technological design and implementation of sustainability projects so that they reflect a broader set of values.

Environmental justice scholars have noted the inherent overlap between sustainability and social justice concerns, offering that "a truly sustainable society is one where wider questions of social needs and welfare, and economic opportunity, are integrally related to environmental limits imposed by supporting ecosystems." ${ }^{\prime 35}$ Efforts to infuse the practices surrounding sustainability with elements of environmental justice will be critically important as cities across the U.S. move to impose narrowly constructed sustainability initiatives. As the case of North Williams has shown, there are moments where the nature of sustainable planning can be called into question; it is imperative that such moments are seized and acted upon if future visions of urban sustainability are to be more inclusive and representative.

Address correspondence to: Amy Lubitow Department of Sociology Portland State University 1721 SW Broadway

Cramer Hall 217 Portland, OR 97201

E-mail: alubitow@pdx.edu

\footnotetext{
${ }^{35}$ Agyeman, Bullard and Evans, 2002: 78.
} 